細菌性腹膜炎下の結腸縫合創治癒に関する実験的研究

\author{
利歌山步立垁科人学消化器外科（主低: 勝見正治教授） \\ 腐、画耕二

\section{EXPERIMENTAL STUDIES ON HEALING OF SUTURED COLONIC WOUNDS UNDER BACTERIAL PERITONITIS}

\author{
Kohji HIROTA \\ Department of Gastrointestinal Surgery, Wakayama Medical College \\ (Director: Professor Masaharu Katsumi)
}

\begin{abstract}
結腸穿孔腹膜资の結腸縫合創治瘾に及ぼす影響についての研究は少なく, 従って細菌性腹膜炎下で, いかなる処置を行えば結腸吻合が安全かといら明確な結論が得られていない．著者は独自の方法で成 犬61頭に細菌性腹膜炎を作製し，さらに68頭を用い，腹膜炎下で結腸創の縫合を行い，腹腔内処置法 として非治療群, 生食水洗浄群, 生食水洗浄後 polyvinylpyrrolidone iodine 撒布群, 同じく heparin 撒布群, 同じく抗生剂撒布群の 5 群に分け効果を検討した。その結果, 抗生剂撒布群が死亡率 $7.1 \%$, 縫合不全率 $3.5 \%$ と最良で, さらに, 腹膜资の程度, 腹水中細菌数, 縫合部療着, 而圧試験, 病理組織 検査においても優れた成績を示した。
\end{abstract}

索引用語：実験的腹膜炎, 腹膜炎下結腸縫合, 結腸縫合創治知

\section{I . 緒 言}

近年, 細菌性腹膜炎の治療は抗生剂と外科学の進歩 により臨床的にかなりの治療成績がえられているが, 腹膜炎下での結腸吻合の適応に関してはいまだ問題点 が多い，事実教室では過去数年間にわたり結腸吻合に 関する研究が行われ，臨床的に Gambee一列縫合によ り释合不全率の減少 (1.4\%)を扣さめてきたが, 腹膜 炎下での縫合不全率は $28.5 \%(2 / 7)$ とな拉高率で満足 すべき成績を兄ていない，また文献的にも過去 10 年間 の本邦での腹膜炎下の一期的結腸吻合132例を集計し てみると縫合不全率は35.6\% (47/132) である. 一方, 古く1889年 Mikulicz が穿孔腸管を腹壁外に脱出させ 固定するMikulicz 術式を発表して以来, 人工肛門造 設術などを含め一期的結腸吻合をさける術式が主流を なしてきた感がある。この理由の 1 つに実験的腹膜炎 の作製が非常に難かしく, 従って一期的結腸吻合の是 非に関する研究が乏しかったことがあげられよう，文 献的にみると実験的腹膜炎の作製方法は, 盲腸の切 開1), 虫垂の結柇2), 回腸盲管の作製3), 䔬便の注入など の多くの方法がみられるが，いずれも極めて短期間で
死亡するといら久点があり, 結腸吻合の研究に用いる モデルとしては適当ではない。

そこで, 著者は細菌浮遊液にゲル状寒天を混入する 独自の方法で腹膜炎を作製し, 細菌性腹膜炎下の一期 的結腸吻合は果して適応があるのか，あるとすればい かなる処置のるとで縫合が安全に行いうるのかを雑種 成犬を用いて検討した。

\section{II. 実験 I：実験的腹膜炎の作製}

\section{1 実験目的}

腹腔内に細菌を含むゲル状寒天を注入し, 腹膜炎の 程度および生存期間を検討して, 結腸縫合創治瘾の研 究に用いるモデルとして理想的な菌種と細菌量を求め るのを目的とした。

\section{2 実験対象ならびに方法}

細菌を含有する寒天の作製は18２4時間 heart infusion broth で細菌を培養し, その細菌浮遊液 $8 \mathrm{ml}$ を採取し $3 \%$ 寒天 $2 \mathrm{ml}$ と混入することによって作製 した. 寒天内の細菌数はほほ $10^{9} / \mathrm{ml}$ であった。 まず体 重 8 15kg の雑種成犬30頭を用い, 手術24時間前から 絶食とし経口水分のみをとらせ,術直前に排便させて, 
GOF 気管内挿管麻醉下に約 $3 \mathrm{~cm}$ の正中切開で開腹 し，上記ゲル状寒天を腹腔内に注入した。菌種及び細 菌量は Klebsiella (以下 Kleb とす) $5 \times 10^{8} / \mathrm{kg}$ (10頭), Kleb +E.coli $5 \times 10^{8} / \mathrm{kg}$ (10頭), Kleb +E.coli $10^{9} / \mathrm{kg}$ (10頭)の 3 群とし，死亡率について検索した。ささらに これとは別に成犬 31 頭を追加し, Kleb+E.coli $5 \times 10^{8} /$ $\mathrm{kg}$ を用い以下の項目について検討した.

3 測定項目

A) 死亡率

細菌注入後腹膜炎に対する治療・処置を一切せず， 腹膜炎作製後 1 日目の死亡率および 7 日目までの累計 死亡率をみた。

B）腹水中細菌数および腹水量

屠殺時の腹水を採取し，腹水 $1 \mathrm{ml}$ 中の細菌数を Urotube Roche ${ }^{\circledR}$ で培着測定した。合わせて全腹水を 計測し 4 段階に分類した。

C) 腹膜炎の程度

上記腹水中細菌数に加兄，屠殺時の腹腔内の発赤， 出血斑, 膿苔, 腹水, 瘾着の肉眼所見を各々 0 一卅の 4 段階とし，Grade Iは肉眼所見で（+）2 2 コ上で (H) 1 コ以下もしくは細菌数が $10^{3} / \mathrm{ml}$ 以上, 同しくく Grade IIは（\#）2コ以上で（冊）1コ以下もしくは $10^{6} / \mathrm{ml}$ 以上，同じくGrade IIIは (\#) 2 二以上もしく は $10^{9} / \mathrm{ml}$ 以上と分類した。

D） 血中 endotoxin 及び血液培養

細菌注入後 30 分， $1 \cdot 2 \cdot 3 \cdot 4 \cdot 5 \cdot 6$ 時間扣上 び $1 \cdot 3 \cdot 5 \cdot 7$ 日目に約 $5 \mathrm{ml}$ の末梢静脈血を採取し, Limulus Test Wako ${ }^{\circledR}$ で endotoxin の有無を検した。 同時に約 $3 \mathrm{ml}$ の末梢血を採取し, heart infusion broth で細菌を培養し，陽性例については確認培地で菌種を 確認した。

E) 組織学的検索

屠殺後 A. mesenterica caudalis の分岐部近傍の結 腸を取り出し， $10 \%$ formalin 固定後 HematoxylinEosin 染色を行った.

\section{4 実験結果}

\section{A) 死亡率}

30 頭の内 Kleb $5 \times 10^{8} / \mathrm{kg}$ 群は 1 日目 1 頭 $(10 \%) 7$ 日目までに 4 頭 (40\%) が死亡し，これに対し Kleb+ E.coli $5 \times 10^{8} / \mathrm{kg}$ 群は 1 日目 2 頭 (20\%) 7 日目までに 5 頭 (50\%) の死亡であったが, Kleb+E.coli 109/ $\mathrm{kg}$ 群は 1 日目 6 頭 $(60 \%) ， 7$ 日目までに 9 頭 $(90 \%)$ が 死亡した。すなわち，死亡率では菌種間に大差は認め ない。
B）腹水中細菌数および腹水量

追加した31頭では, 細菌数は 1 日目で $10^{5} \sim 10^{6} / \mathrm{ml}$ であったが，7 日目には $10^{3} / \mathrm{ml}$ 前後となった。しかし 腹水量は 3 日目以後著明な減少はなく, 腹腔内の総細 菌量としては3 日目以後は減少していないと判断でき た（図 1).

C）腹膜炎の程度

追加した31頭について, 腹膜炎の程度を先に示した Grade に従い経日的にみると，1日目では Grade IIが 9 頭, Grade IIIが 1 頭であったが，日を増すごとに腹 膜炎は軽微となり，7 日目には Grade I が 3 頭, Grade II が 4 頭であった（図 2 ）.

図 1 実験的腹膜资における腹水中細菌数 ( $1 \mathrm{~m} l$ 中) 及び腹水の程度の推移

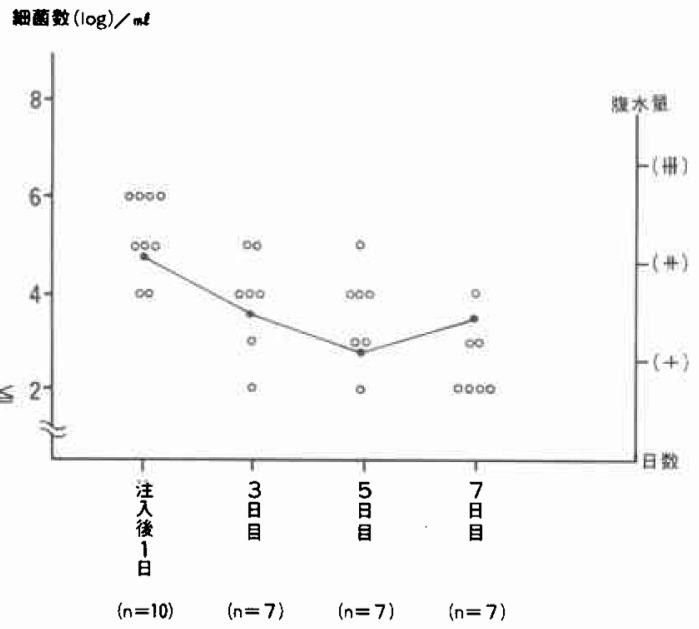

〔注〕○は絧菌数

- 比腹水量

図 2 実験的腹膜炎重症度の推移

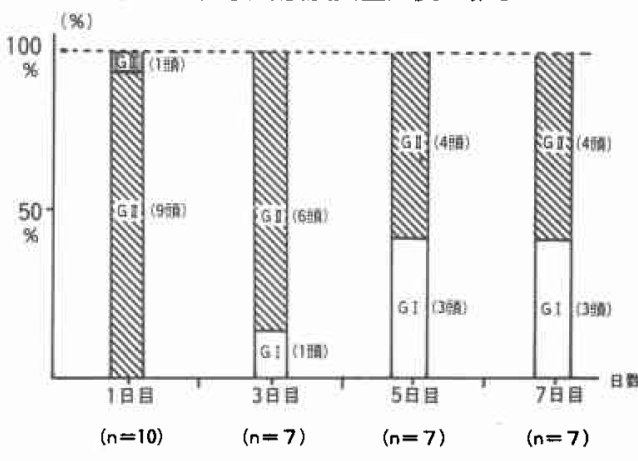

[注] 
D）血中 endotoxin 抢よび血液培養

同じく31頭の内, 細菌注入後 30 分・ 5 時間・ 6 時間・ 1 日・7日の計 6 頭が endotoxin 陽性で，その陽性率 は5.9\%（6/101）と低率であった。また血液培養は 1 日目の 2 頭の夕陽性で，これも $1.9 \%(2 / 101)$ と低率 であった。

E) 組織学的検索

同じく31頭において, 結晹漿膜面の多核白血球浸潤, fibrin 析出, 出血, 円形細胞浸潤，肉芽組織の増生の 5 項目を 0 一卅の 4 段階に分け, 各々に対し $0 \sim 3.0$ 点 数を定め, その平均值で判定した。多核白血球浸潤, 出血の 2 項目は 1 日目が最も強く, 以後経日的に軽減 した. また fibrin 析出は 3 日目が最も強く, その後軽減 した.これに対し，円形細胞浸潤は 1 日目は殆んど認 められず，5日目で最も強く存在し，肉芽組織もこれ と同じ傾向を示し 7 日目で最も強かった（図3・写真 1).

\section{5 小括}

実験的腹膜炎の作製には細菌を含有する半流動性寒 天 $5 \times 10^{8} / \mathrm{kg}$ の注入が, 死亡率の点から最も適当であ り, 細菌の種類による死亡率の差は認められなかった。 $5 \times 10^{8} / \mathrm{kg}$ 注入群の腹膜炎の程度は第 1 日目で, ほ Grade IIを示し，7日目においても Grade IIのものが 半数をこえていた。ささらに腹水中の細菌は 1 週間を通 じて存在し, 組䅧学的にも結腸の漿膜面に资症所見が 7 日間認められた，以上の結果, 細菌を含有する半流 動性寒天を使用した実験的腹膜炎は, 腹膜资自身均一 で長期間持続し，結腸縫合創治瘾の研究に用いる実験

図 3 実験的腹膜炎の結腸漿膜の病理所見推移

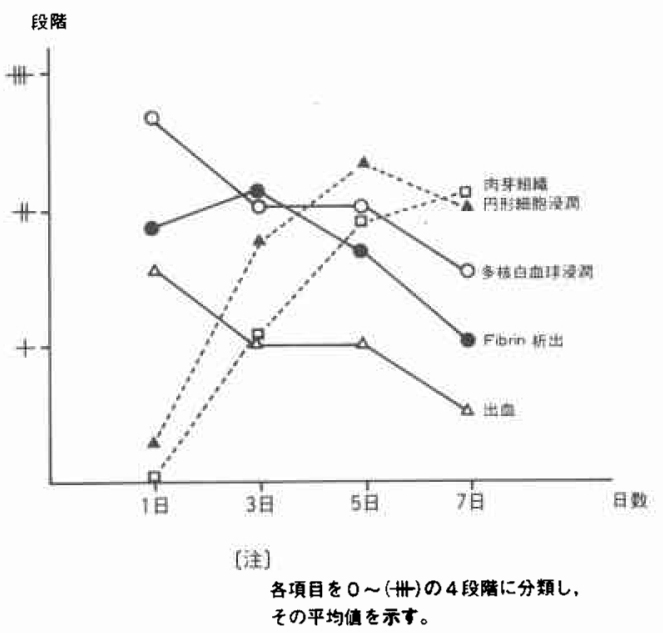

孛其 1 腹膜炎作製 1 日目の結腸漿膜病理組織像 $(\times 40)$

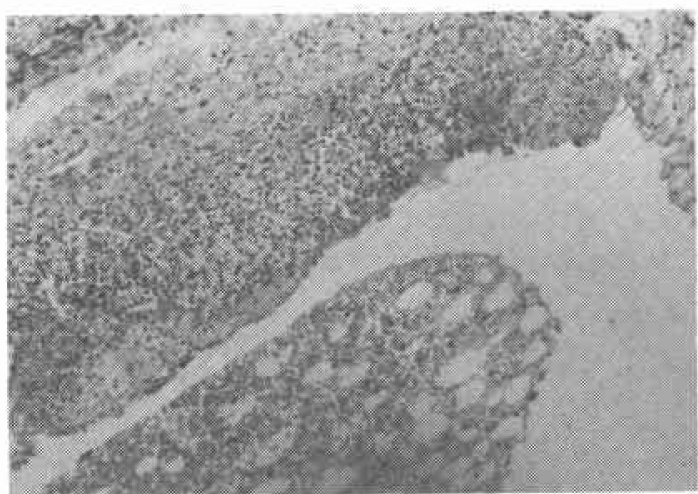

的モデルとして適当であることが判明した。

\section{III. 実験 II：細菌性腹膜资下の結腸䋖合創治瘦}

\section{1 実験目的}

細菌性腹膜炎下で結腸縫合を行い，同時に各種の腹 腔内治療を施行し，その縫合創治瘾に及注す影響につ いて検討するのを目的とした。

\section{2 実験対象ならびに方法}

体重 8 15kg の雑種成犬68頭を用いた。

\section{A）非腹膜炎下結腸縫合群 (control 群)}

雑種成犬13頭を用い, 術前処置は実験 I と同様にし, $\mathrm{GOF}$ 気管内捙管麻酔下に約 $10 \mathrm{~cm}$ 長の正中切開で開 腹した。結腸の A. mesenterica caudalis の分岐部とそ れより $5 \mathrm{~cm}$ 口側の 2 ケ所で結腸間膜対側で約 $2 / 3$ 周の 切開を行った後，3ー0 P.G.A.系（Dexon ${ }^{\circledR)}$ を用い Gambee 1 列縫合を行って閉腹した.

B）腹膜炎下結腸縫合

雑種成犬55頭を用い, 実験 I の方法により Kleb+E. coli $5 \times 10^{8} / \mathrm{kg}$ の腹膜炎を作製し， 24 時間後に気管内 插管麻酔下に再開腹した，結腸の切開预よび縫合は control 群と同一方法で行った. 尚, 結腸縫合後以下に 示す 5 群の腹腔内治療を同時に行った。
a) 非治療群
b）生食水洗浄群 布群 (以下 PVP-I 群とす)
d）生食水洗浄後 heparin 撒布群
e）生食水洗浄後抗生剂撒布群

c）生食水洗浄後 polyvinylpyrrolidone iodine 撒

なお, PVP-I (Isodine ${ }^{\circledR)}$ は有効 $ョ$ ド0.1\%で $10 \mathrm{ml} / \mathrm{kg}$ 使用し, heprain 200 単位 $/ \mathrm{kg}$, 抗生剂は cephalotine $2 \mathrm{~g} / \mathrm{dog}$ を使用した。またこれら腹腔内治 
療とは別に全身的治療として, a)〜e)の各群に cephalotine $2 \mathrm{~g} / \mathrm{dog}$ の点滴静注を術当日と術後 1 ・ 3 ・5・ 7 日目に行った。 control 群及び各種腹腔内治療群と も縫合後 $1 \cdot 3 \cdot 5 \cdot 7$ 日目に屠殺剖検し, 以下に述 べる各項目について縫合部の治瘦状態を検索した。

3 検索項目

A）死亡率拉よび死亡原因の探索

縫合後 7 日目までの死亡率を算出し，その死亡原因 について検討を加えた。

B）腹膜炎の程度

実験 I に打ける腹膜炎の程度の基準に従い判定し， 縫合後 $1 \cdot 3 \cdot 5 \cdot 7$ 日目で屠殺剖検し, Grade I 〜Grade III の段階で判定した。

C）腹水中細菌数の推移

屠殺時の腹水を採取し, 腹水 $1 \mathrm{ml}$ 中の細菌数を Urotube Roche で培養測定した。

D）屠殺時縫合不全率

屠殺時の縫合部の状態を十分観察し，一見して判る
大きな縫合不全から，縫合部の瘾着を剝離して初めて 判るピンホール程度のものまで全て縫合不全とみなし て検討した。

E）屠殺時縫合部窟着

勝部凹の癒着判定基準を参考にして採点し，その平 均値を用いた。

F) 耐圧試験

居殺後直ちに縫合部を中心に約 $10 \mathrm{~cm}$ 長の結腸をと ク出し、一方を盲端にして, 他端にチューブを連結し, 縫合腸管を水中に没して压を加党, 注入加圧した色素 水が縫合部から漏れる時の王を水銀計で測定するいわ ゆる liquid inflation leak testを用いた。

G）組織学的検索

释合部を中心に結腸を取り出し，10\%formalin 固定 後 Hematoxylin-Eosin 染色を行った。

\section{4 実験結果}

A）死亡率招よび死亡原因

control 群の死亡率は7.6\%（1/13）で，死因は縫合

\section{表 1 実験的腹膜炎下の結腸释合 \\ 1 - a . 使用頭数及び死亡率 \\ 1 - b. 醍合不全華

$$
1-\mathbf{a}
$$

（）内は死亡歌

\begin{tabular}{|c|c|c|c|c|c|c|}
\hline 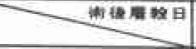 & 1 日 & 3日 & 5日 & 7 日 & 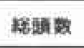 & 歹士末 \\
\hline 非酳炎 (Control) & $3(0)$ & $3(0)$ & $4(1)$ & $3(0)$ & $13(1)$ & 7.6 \\
\hline \multicolumn{7}{|l|}{ 背紧炎 F } \\
\hline 非治是 & $3(1)$ & $3(1)$ & $3(0)$ & $3(0)$ & $12(2)$ & 16.6 \\
\hline 洗沙のみ & $3(1)$ & $2(0)$ & $2(0)$ & $2(0)$ & $9(1)$ & 11.1 \\
\hline 洗浮 +PVP-1 & $3(0)$ & $3(1)$ & $2(0)$ & $2(0)$ & $10(1)$ & 10.0 \\
\hline 洗海 +Heparin & $2(0)$ & $2(0)$ & $3(1)$ & $3(0)$ & $10(1)$ & 10.0 \\
\hline 洗浄十扰生都 & $4(0)$ & $4(1)$ & $3(0)$ & $3(0)$ & $14(1)$ & 7.1 \\
\hline
\end{tabular}

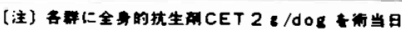

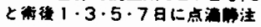

\begin{tabular}{|c|c|c|c|c|c|}
\hline 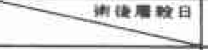 & 1日 & 3 日 & 5 日 & 7 日 & it \\
\hline 非留数 (Control) & $0(0 / 6)$ & $0(0 / 6)$ & $12.5(1 / 8)$ & $0(0 / 6)$ & $3.8(1 / 26)$ \\
\hline 具觉炎下 & \multirow[b]{2}{*}{$33.3(2 / 6)$} & \multirow[b]{2}{*}{$33.3(2 / 6)$} & \multirow[b]{2}{*}{$16.6(1 / 6)$} & \multirow[b]{2}{*}{$O(0 / 6)$} & \multirow[b]{2}{*}{$20.8(5 / 24)$} \\
\hline 非治策 & & & & & \\
\hline 洗棌のみ & $33.3(2 / 6)$ & $0(0 / 4)$ & $0(0 / 4)$ & $0(0 / 4)$ & $11.1(2 / 18)$ \\
\hline 洗棌 +PVP-1 & $16.6(1 / 6)$ & $16.6(1 / 6)$ & $0(0 / 4)$ & $0(0 / 4)$ & $5.0(1 / 20)$ \\
\hline 洗海+Heparin & $50(2 / 4)$ & $0(0 / 4)$ & $16.6(1 / 6)$ & $O(0 / 6)$ & $15.0(3 / 20)$ \\
\hline 洗棌十执生都 & $12.5(1 / 8)$ & $0(0 / 8)$ & $O(0 / 6)$ & $0(0 / 6)$ & $3.5(1 / 28)$ \\
\hline
\end{tabular}

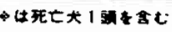

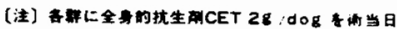

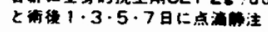


不全であった. control 群を除いた55頭の死亡率は $10.9 \%(6 / 55)$ で, 死亡原因は縫合不全 2 頭, 強度の 腹膜炎 1 頭, 開腹創哆開 1 頭であった。腹腔内治療別 に死亡率をみると, 非治療群は $16.6 \%$, 洗浄群 $11.1 \%$, PVP-I 群10\%, haparin 群10\%，抗生剂群7.1\%で, 非治療群を除いて腹腔内治療別には明らかな差はな かった（表 1一a).

B）腹膜炎の程度

各群とも Grade I 〜III合わせて点数を1.0〜3.0 と定め, その平均値で評価した。最も強い腹膜炎を示 した群は非治療群で, 3 日目においても Grade IIを示 した。これに対して 7 日間を通じ最す軽微であったの が heprain 群で, 7 日目には control 群と差はなかっ た。その他の群はこの両者の中間に存在した（図4）.

C) 腹水中細菌数の推移

腹水 $1 \mathrm{ml}$ 中の細菌数を求め, その平均值をもって表 わした. 各群とも洗浄前の細菌数は $10^{6} / \mathrm{ml}$ 前後で あったが, 洗浄を行った 4 群は洗浄直後は明らかに細 菌数の減少を認めたが, 術後 1 日目以後には再び細菌 数の増加を示すパターンをとった。 しかし, 抗生版群 が術後 3 日目以後最も細菌数が少なく, $10^{2} / \mathrm{ml}$ 以下を 示し control 群とほ涪差を認めなかった。さらに heparin 群も良好な結果を示し, PVP-I 群, 洗浄群は 細菌数がやや多く認められた。これに対し非治療群は 7 日間を通じ最も細菌数が多く存在した（図 5).

洗浄による効果を検討したところ, 生食水 $500 \mathrm{ml}$ 使 用後の細菌数は非常に減少し, さらに $1000 \mathrm{ml}$ 使用後 には $10^{2} / \mathrm{ml}$ 以下のものが殆んどであった。このこと より成犬での腹空内洗浄には生食水 $1000 \mathrm{ml}$ が適当と 考えられた（図6）。

図 4 腹膜炎の程度の推移

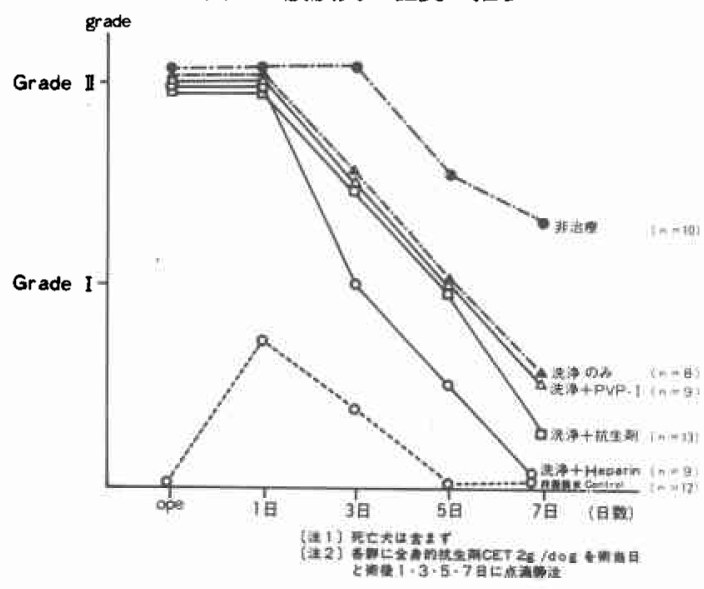

図 5 腹水中 $(1 \mathrm{~m} l)$ 細菌数の推移

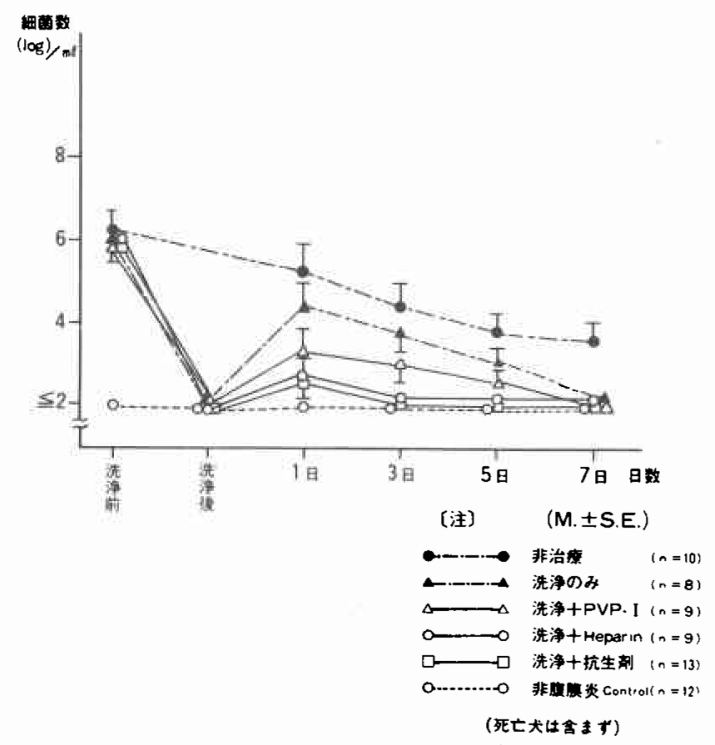

圆 6 洗潼後腹水中 $(1 \mathrm{~m} l)$ 細菌数

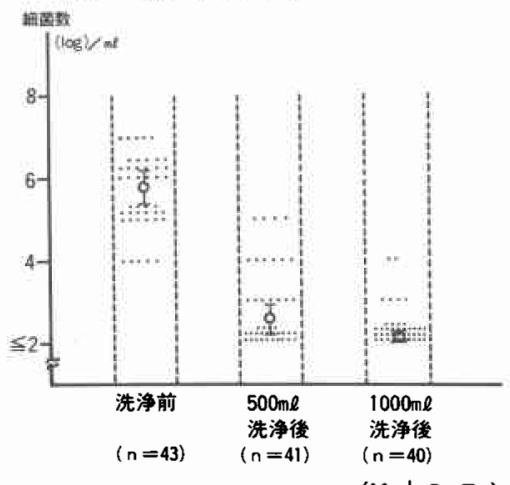

(M. \pm S.E.)

\section{D） 屠殺時縫合不全率}

control 群は $3.8 \%$ の縫合不全率であったが, 腹膜炎 下縫合を行ったものの内, 非治療群は $20.8 \%$, heparin 群 $15 \%$, 洗浄群 $11.1 \%$ と悪く, これに対して PVP-I 群 $5.0 \%$, 抗生剂群 $3.5 \%$ と良好な結果を示した。術後 日数別では heparin 群の 1 日目が50\%と高率を示し， 縫合部に対しては悪影響を示した（表 $1 ー b)$.

E）屠殺時縫合部撚着

腹腔内治療別に比較すると, 非治療群の 7 日目, PVP-I 群の 7 日目に強度の瘾着が認められたが, こ れに対して, heparin 群は $1 \cdot 3 \cdot 5 \cdot 7$ 日目とすべて に掞いて control 群よりも低值を示し, 瘺着が軽微で あった（表2). 
表 2 屠殺時絴合部䒴着（点数*）

\begin{tabular}{|c|c|c|c|c|}
\hline & 霜得1日 & 38 & 5日 & $7 日$ \\
\hline 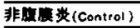 & 0.8 & 1.2 & 1.0 & 0.8 \\
\hline \multicolumn{5}{|l|}{ 是留下 } \\
\hline 非治表 & 0.75 & 1.5 & 1.5 & 2.75 \\
\hline 洗㴆のみ & 1.0 & 1.0 & 1.75 & 20 \\
\hline 洗㴒+PVP-I & 1.5 & 1.5 & 1.75 & 2.5 \\
\hline 洗潼+Meparin & 0 & 0.5 & 0.25 & 0.5 \\
\hline 洗海十抗生阙 & 1.0 & 1.0 & 1.5 & 1.5 \\
\hline \multicolumn{5}{|c|}{ 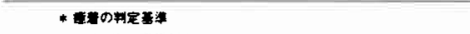 } \\
\hline of & E*to & & & \\
\hline 1. 息 & & & & \\
\hline 2哭 & 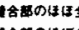 & に用手 & 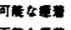 & \\
\hline 3点 & 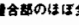 & & 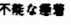 & \\
\hline
\end{tabular}

図 7 縫合部の耐圧試験

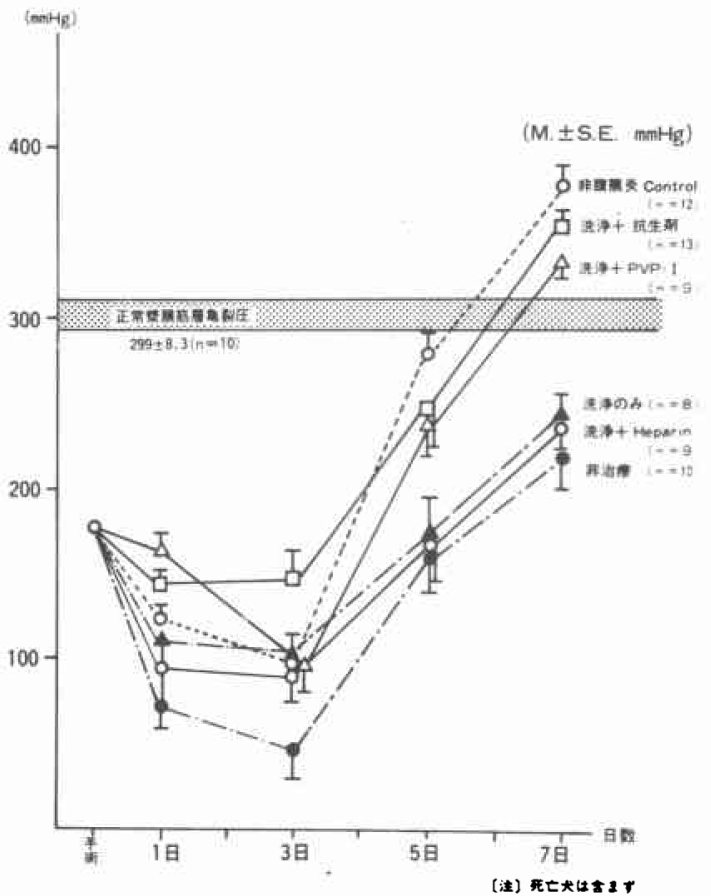

表 3 艇合部病理所見評価

\begin{tabular}{|c|c|c|c|c|c|}
\hline & \multicolumn{3}{|c|}{ I $\sim 3$ B } & \multicolumn{2}{|c|}{$5 \sim 7 日$} \\
\hline & 多核球 & 出 血 & Fibrin 斩出 & 肉芽形成 & 经椎化形成 \\
\hline 非䏹㖏炎 (Control) & $\rightarrow$ & $\rightarrow$ & $\rightarrow$ & $\rightarrow$ & $\rightarrow$ \\
\hline \multicolumn{6}{|l|}{ 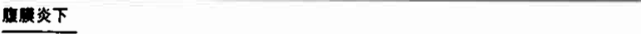 } \\
\hline 非治 & $\pi$ & $\rightarrow$ & $\uparrow$ & $\downarrow$ & $\downarrow$ \\
\hline 洗法のみ & $\Uparrow$ & $\rightarrow$ & $\uparrow$ & $!$ & $\downarrow$ \\
\hline 洗海+PVP-1 & $\uparrow$ & $\rightarrow$ & $\rightarrow$ & $\rightarrow$ & $\rightarrow$ \\
\hline 洗㴔+Heperin & $\uparrow$ & $\Uparrow$ & $\rightarrow$ & $\rightarrow$ & $\downarrow$ \\
\hline 洗潘十沉生刷 & $\uparrow$ & $\rightarrow$ & $\rightarrow$ & $\rightarrow$ & $\rightarrow$ \\
\hline
\end{tabular}

\section{F） 耐圧試験}

耐王試験は各群とも術後日数別に縫合部 3 カ所につ いて行った. control 群を含め各群とも3日目に最低 值を示した.なかでも最低値を示したのか゚非治㞠群で, 1 日目 $56.6 \pm 12.0 \mathrm{mmHg}, 3$ 日目 $40 \pm 5.7 \mathrm{mmHg}$ を示
し，5日目になると $160 \pm 5.7 \mathrm{mmHg}$ で， control 群の $257 \pm 10.3 \mathrm{mmHg}$ に比へ有意に低く $(\mathrm{p}<0.01)$, さらに 7 日目です $203 \pm 14.5 \mathrm{mmHg}$ と control 群の $357 \pm 10$. $3 \mathrm{mmHg}$ に比べ有意に低値を示した $(\mathrm{p}<0.001)$. 同じ く洗浄群及び heparin群とも5 日目 $(\mathrm{p}<0.01)$, 7 日目

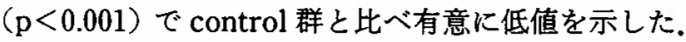
これに対し抗生剂群と PVP-I 群は control 群とは ば差はなく，5日目，7日目において耐圧力の回復を 示した。なお正常犬の結腸の漿膜筋層亀裂圧は10頭平，

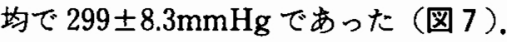

G）組織学的検索

組織学的所見として縫合部の多核白血球の浸潤，出 血, fibrin の析出, 肉芽形成, 線維化形成の程度を 0 点 （0）から 3 点（卅）までの 4 段階に分けて判定し，そ の平均値を用い control 群を基準とし，これより低值

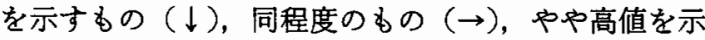

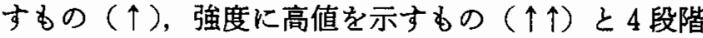
に分け評価した. 術後 1 日目から 3 日目の特徵として, 多核球浸潤は非治療群と洗浄群において強度に認めら れるほか，その他の群でも中等度認められ，出血は heparin 群に強度に存在し, fibrin の析出は非治㞠群, 洗浄群において中等度認められた。 5 日目から 7 日目 の特㮹としては，肉芽形成および線維化形成では非治 療群および洗浄群が低値を示し，創治诙の覀さがらか

\section{写真 2 䋖合部病理組織像}

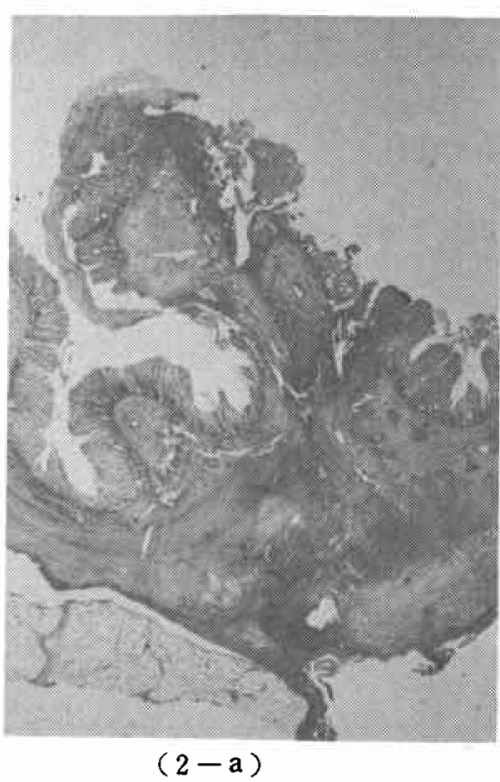

非治療群 稌合後 7 日目 $(\times 10)$ 


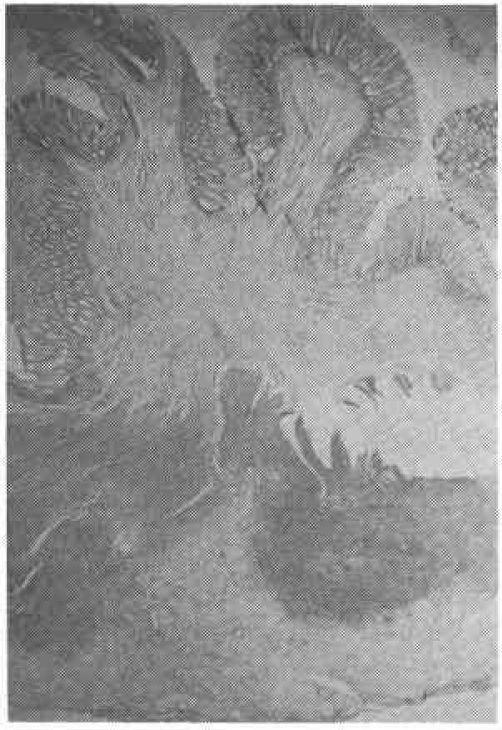

$(2-b)$

抗生剂群 縫合後 7 日目 $(\times 10)$

がえた。おた heparin 群において線維化形成の悪さが 認められた（写真 3 , 写真 $2-a, 2-b)$.

5 小括

死亡犬は非治療群を除き腹腔内治療法別にみて明ら かな差は認められなかった。

腹膜炎の程度はもちろん非治療群が最も強く, 治療 群では heparin 群が最も軽微であった。

腹水中の細菌数に扎いては heparin 群, 抗生剂群が 低值を示した．また成犬での腹腔内洗浄は腹水中の細 菌の减少程度からみて $1 \ell$ が適当であった。

屠殺時縫合不全率は非治療群で20.8\%, heparin 群 で15\%と高く，逆に抗生剂群は3.5\%と低率であった。

屠殺時の縫合部癒着は非治療群と PVP-I 群が強 く, heparin 群は非常に軽微であった。

耐圧試験では heparin 群, 洗浄群は非治療群と同程 度に不良であり, 逆に抗生剂群, PVP-I 群は control 群と同程度に良好であった。

組織学的所見では heparin 群は縫合部漿膜面に出血 が強く, 非治療群および洗浄群は肉芽形成, 線維化形 成がやや不良であった。

\section{IV. 総括および考案}

臨床上，腹膜炎下で一期的結腸吻合を行なった場合 の縫合不全率について述べた報告は少ないが，小暮 $ら^{5)}$ は22.5\% (7/31) 森谷ら ${ }^{6)}$ は25\%(4/16) と報告し ている，そこで著者は本邦での過去10年間に報告され
た文献症例を集計し縫合不全率を算出したところ $35.6 \%(47 / 132)$ となり，教室における腹膜炎下結腸 縫合不全率 $27.3 \%$ とほ注同程度であった。ささらに死亡 率をみると，鈴木らりは40\% (14/35)，加藤ら ${ }^{8)}$ は $25 \%$ (3/12) と述べている. 欧米では Whelan ら99は28\%, Kenneth は21\%（37/180） と報告し，いずれも死亡率 は高い。このように腹膜炎下にお打る結腸吻合は, 待 期的手術に比べ縫合不全率, 死亡率ともに高く, 適応 に関する文献的報告をみても，結腸穿孔の腹膜炎時に は縫合不全の危惧から一期的吻合はすべきでないとい ら報告 ${ }^{11)}$ と，積極的に吻合すべきであるという報告8) に分かれているのが見状である，そこで著者は細菌性 腹膜炎下での一期的結腸吻合は果して適応があるの か，あるとすれば何如なる処置を行党ば吻合がより安 全であるのかの問題に解答すべく今回の実験を行っ た。

〈実験的腹膜炎作製方法について〉

実験的腹膜炎の作製に関しては外科的作製法と細菌 注入作製法に大別できる。外科的なものでは結腸・盲 腸の切開1), 虫垂結禁・切開2), 回腸盲管作製と血行遮

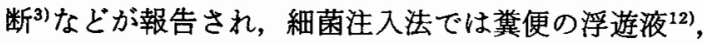
細菌培養の浮遊液 ${ }^{18220)}$ の注入がある。しかし上記方法 では，腹膜炎作製後実験動物は数時間で死亡し，腹膜 炎自身す均一性にかけることが多い理由から，諸家は 種々の工夫をこらしてきた。例えば, gelatin capsule ${ }^{14)}$ の細菌を他の物質に包みこんで注入する方法や, 血液 とかへモグロビン15)16), 硫酸バリゥム ${ }^{14)}$, bile salts ${ }^{17)}$, 殺菌した䔬便 ${ }^{13)}$ な゙を細菌と混入する報告がみられ る. へモグロビンを泿入する理由について Filles ら ${ }^{15)}$ は腹膜の吸収能が低下し, 注入後 5 時間では腹腔内細 菌数はへモグロビンを混入しない場合の1000倍である 事からと述べている，またToni Hau ら ${ }^{16)} は$ まへモグ口 ビンは白血球，とくに多核球の腹腔内への遊走を拉さ え，白血球の働きを抑制しているためと結論している. さらに葛西ら ${ }^{18}$ は䔬便を混入する理由として，その異 物性と proteolytic enzyme の作用をあげている。しか し，これらいずれの方法でさえなお実験動物が短時間 で死亡し，腹膜炎の均一性がかける点があった。これ らは細菌の払散が良いため腹膜の自浄作用により早く 細菌が吸収され腹膜炎が生じにくかったり，逆に腹膜 炎が生じて, 腹膜からの細菌・endotoxin などの吸収が 急速に生じるためショック死などが起こっていたもの と推定される。この点著者の作製した腹膜炎は半流動 性寒天により, 細菌そのものの拡散をある程度おさ光 
て細菌の focus を作る点と, 寒天中に細菌が存在する ため細菌・endotoxin の腹膜からの吸収が徐々に起こ る事により,ショック等の死亡がさけられたものと思 われる.

〈各種腹空内治療について〉

著者の成績では腹腔内洗浄に抗生剤を併用した場 合，7 日間を通じ死亡率 $7.1 \%$, 縫合不全率 $3.5 \%$ と低 率で，さらに耐圧力に至っては最も弱い 3 日目でさえ 6平均 $140 \mathrm{mmHg}$ と良好な結果を示し，非腹膜炎の control 群とほぼ差のない創治痖過程を示した。この ように腹腔内洗浄に併用した種々の抗生剂, サルファ 剤の腹空内投与の報告は臨床的または実験的にも数多 く認められ，腹膜炎の治療の1つの方法として広く用 いられているのが現状である。しかし，腹膜炎に対す る効果は一般に認められていても，腹膜炎下での結腸 吻合の場合に腹腔内の抗生剂投与がいかなる結果をも たらすかという報告は少なく，さらにその種々なる治 療法との比較検討された報告となると皆無に等しい。 抗生剂のなかった過去において，腹膜炎手術時の腹腔 内洗浄は腹膜炎をかえって质げるため禁忌とされてい た時期もあったが，腹腔内洗浄を行い臨床上にはじめ て好成績を扰さめたのは1957年の Burnett ${ }^{19)}$ の報告で あった. Burnett らは生食水洗浄を行いその後抗生剂 として高濃度の penicillin と streptomycin を腹空内 に投与し死亡率の低下をもたらした，その後，抗生剂 と洗浄併用を推奖する数多くの報告があり，近年では 1978年 Stewart ${ }^{12)}$ が虫垂炎の穿孔189例に抗生剂（tetracyclin $と$ noxythiolin)入りの洗浄を行い, 洗浄をし なかったものより入院期間が短縮できたとし，1979年 にはStephen ${ }^{20}$ が持続的な抗生剂入りの洗浄を行い死 亡率の減少を得ている。また本邦に打いても1969年大 島 ${ }^{21)}$ が穿孔性腹膜炎時の抗生剂腹腔内投与について 実験的および臨床的に有効であったとし，さらに1971 年渡辺ら ${ }^{22}$ が 156 例の腹膜炎の治療に際し, 十分な腹腔 内洗浄と病巣切除および術後の強力な抗生剂投与によ クドレーンなしにきわめて良い成績をあげることがで きたと報告している。これに対し実験的報告では, 1969 年 Sleeman ${ }^{23)}$ はラットで腹腔内洗浄を行い抗生剂の 腹腔内投与を併用し腹膜炎に良好な結果をるたらした 之述べ，1972年には Rosato ${ }^{3)}$ が成犬で洗浄のみの効果 を検討し，死亡率の著しい減少を報告している。

腹膜炎の他の治療法として洗浄液に PVP-I を使 用する方法があり, 著者の成績では PVP-I は縫合部 癒着が強く， 7 日間の死亡率 $10 \%$, 縫合不全率 $5.0 \%$ か control 群に比べやや高く, 腹膜炎の治療効果は全体 として抗生剤に及ばなかったが，耐圧力などでは良好 な成績をおさめた。このことは，縫合部の治癒は漿膜 が虚して治ることが 1 つの因子であるから，PVP 一I 群は縫合部の療着が強く生じるために耐圧力の増 加をきたしていると推論される。文献的には1974年に Lavingne ら ${ }^{24)}$ がはじめて実験的腹膜炎に PVP-I を 用い，抗生剤 (cephalotin と kanamycin) と同じ効果 を示し有効であったとし，その濃度は有効ヨード $1 \%$ で $2.5 \mathrm{ml} / \mathrm{kg}$ が適当で, PBI・血中ヨードをも測定し副 作用はなかったと述べている. Gilmore ら ${ }^{25)}$ む PVP 一Iの効果を推奖し抗生剂に匹敵すると報告し，同じ くSindelar ${ }^{26}$ も 細菌の耐性に心配しなくてもよい点 および抗生剤のような感受性試験をしなくてもよい点 を強調している。しかし，このような賛成派に対し一 部の報告では反対の意見もあり，Lagarde ら ${ }^{281}$ は成犬 に腹膜资を作製し PVP一I投与を行ったが生存率は 良くなかったと述べ,腹腔内に PVP-I を残すことは 問題があるとしている. 何れにしてもこれら賛否両方 とも PVP-Iの濃度は有効ヨードではほぼ0.1\%と し, 量は $10 \sim 20 \mathrm{ml} / \mathrm{kg}$ の投与が多く, 著者の実験もこ れに準した。

臨床的に PVP-I 用いた報告は1979年の Sinde$\mathrm{lar}^{26)}$ で, 腹膜炎 168 例の内 80 例に使用し術後膿瘍形成 が 1 例，これに対し生食水洗浄のみの88例中膿湟形成 が 9 例認められ有效であったと報告し，その血中ョー ド量・T $\mathrm{T}_{4}$ 值にも変化はなかったと述べている。

腹膜炎のもう 1 つ治療法に腹空内に heparin を投 与する報告があり，著者の実駼結果からる heparin 治 療性存率も良く, 腹腔内細菌数の減少も早く腹膜炎 そのものの治療としては良好であったが，縫合不全率 が $15 \%$ 之高く，耐圧力の低下などから結腸縫合部には 悪影響を及ぼしていた。このことは heparin の瘾着防 止作用が影響し縫合部の漿膜癒合を防げるためと考兄 られる，今後臨床的な使用方法としては，まだまだ検 討が必要であろうが，腸吻合などを行っていない場合 (人工肛門造設時など)の腹膜资時にその意義があるの ではなからうか。

heparin 投与の報告は，古くは1952年 Zinser ら ${ }^{28}$ )が heparin 化された成犬では腹腔内の細菌が早く浄化さ れると報告している。最近では, 1976年 Toni Hau ${ }^{299}$ が 成犬を用い腹膜炎作製後, heparin 100 単位 $/ \mathrm{kg}$ を腹腔 内に投与し，生存率 $80 \%$ で control の30\%に比し良好 であったとし，抗生剤を使用しなくても腹膜炎の抑制 
ができたと論じている。また O'Leary ${ }^{30)}$ の報告におい ても生存率が良かったとされている。 heparin 治療の 原理は O’Leary ${ }^{30}$ によれば, 「腹膜の癒着とは生体防禦 の 1 つであり, 細菌の拡散を防いでいるのであるが, 腹膜炎時には腹腔内に多くの fibrin の沈着が存在し， これが腹膜本来の㗢きである細菌の浄化をおくらせて いる. heparin はこのような癒着をなくすことにより 腹腔内の細菌の浄化を促進する.」と推論している。こ の heparin 治療に関する臨床的な報告は未だ見あたら ない.

その他の腹膜炎の腹腔内治療法としては，近年超音 波洗浄を行う報告31)もあり，さらに人工腹膜を用い持 続的潅流を行う報告もされている。亦た腹空内の洗浄 に関して，その効果については多くの諸家が認めてい るが，その量については一定していない. Burnett ${ }^{199}$ は $500 \sim 800 \mathrm{ml}$ 程度とし, Stephen ${ }^{201}$ は $6 \ell, \mathrm{McKenna}^{32)}$ は $16 \ell$ とまちまちである。著者はその他文献的に検討 を行ったが，いずれもその洗浄量の根拠については述 ベず，あくまでも各人が経験的に行ってきたのが現状 である。

著者はこの点についても実験で検討を行い, $10 \mathrm{~kg}$ 前 後の成犬での洗浄効果を洗浄液 $500 \mathrm{ml} ・ 1000 \mathrm{ml}$ の各時 点での細菌量より判定し, 成犬では $1000 \mathrm{ml}$ の洗浄で 十分であることを明確にした。

〈腹膜炎の結腸縫合創に及ぼす影響について〉

縫合部の耐圧力から検討してみると, 著者の成績で, 非治療群は術後 3 日目の耐圧力平均 $40 \mathrm{mmHg}$ で最低 を示し (control 群 $83.3 \mathrm{mmHg}$ ), その後も回復が悪く て 7 日目でも $203 \mathrm{mmHg}$ (control 群 $357.5 \mathrm{mmHg}$ ) と 低值を示した。これに対し，抗生剤群は最も良好な耐 圧力を示し，control 群との差は認められなかった。 heparin群は 5 日目・7日目になってもそれぞれ $153 \mathrm{mmHg}, 230 \mathrm{mmHg}$ と耐圧力の回復が悪く, 興味あ る結果をるたらした，文献的には1967年 Letwin ら ${ }^{33)}$ はラット小腸で腹膜炎下ではじめて吻合部耐圧力を測 定し, 術後 3 日目では正常吻合部の圧よりも55 70\% の低下が認められたと述べ，その後 Kilam ら ${ }^{34)}$ も同じ くラット小腸を用い吻合と同時に細菌性腹膜炎を生じ させ経日的に吻合部耐圧力を測定し，その脆弱性を検 討している，それによれば，耐圧力は吻合後 3 日目が control との差が大きく, 細菌では大腸菌が最も強い 影響を及ぼしたと報告さ玌ている。1970年には Hawley ${ }^{35)}$ がラビット結腸を用い腹膜炎発生による吻合部 耐圧力の低下を論じている。
さらに病理組織学的な面からみるとどうであろう か. まず正常結腸の縫合創治瘾過程に関する現在の報 告をまとめてみると，縫合創の初期には創面およびわ ずかに残された創空に fibrin や血小板が沈着し，白血 球・組織球等の炎症性細胞が創部に集まり，3〜4 日 頃より線維芽細胞の増殖や新生毛細管ができ， 5 日目 頃には膠原線維が沈着しはじめ, 上皮の再生も認めら れるようになり, 抗張力・耐圧力も増加して, 順調に 経過すれぱほぼ 2 週間で創瘦痕が完成する、著者の実 験での control 群の創治療はこれと同じ経過をとって いる．そこで腹膜炎はいかなる機転で創治虑に悪影響 を及活しているのかを病理組織学的な面を中心に考兄 てみたい，腹腔内に感染が生じることで予想される主 な影響は(1)參出液による影響(2)多核白血球の浸潤によ る影響(3)細菌及び細菌毒素の影響(4) collagenase によ る影響，その他多くの因子が考学られる。

(1) 出液による影響

細菌が生体に侵入することにより生じる生体反応の 第 1 は炎症性充血で，血管壁の透過性が高まることに より細胞成分が血管外に渗出する。とくに細菌感染に よる場合血漿蛋白の渗出は高度となり，このことが直 接肉芽形成を阻害する ${ }^{36)}$ とも言われている。ささらにリ ンパ環流にも障害が生じるため渗出液が組織の間隙に 眝溜し, 炎症性水腫 (浮腫)を形成し, 浮腫そのもの

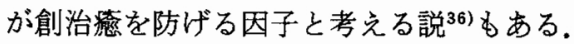

(2) 多核白血球の浸潤

大高ら ${ }^{36}$ によれば細菌感染があれば生体の好中球の 漫潤は著明となり，死減した好中球に由来する一種の 蛋白分解酵素 (proteinase) が肉芽形成の途上の collagen 蛋白に対して障害を与えると推論している. 渡 辺 ${ }^{38)}$ も好中球浸潤のある部位は lysosomal enzyme のためムコ多糖染色が陰性となり, 周辺の線維形成は そしいと述べている。

(3) 細菌及び細菌毒素による影響

細菌の炎症惹起作用は, その新陳代謝の終末産物之 exotoxin および菌体の崩壊により放出される endotoxinの化学的な作用が主であるが，細菌そのものの もつ異物としての物理的な作用も存在する. 大高ら ${ }^{36)}$ は肉芽組織を構成する細胞群に対する endotoxin の 直接的な障害をる推論している。

(4) collagenase による影響

吻合部の collagen が創治癒に重要な役割をしてい ることは, 1887年 Halsted が報告して以来数多くの研

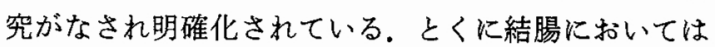


collagenase が他の腸管よりも多く含まれている点が 分ってから諸家の研究の的となっている.1970年 Hawley $ら^{371}$ は結腸の吻合部で腹膜炎下々非腹膜炎下 の collagenase 測定を行い，腹膜炎下の方がかなり高 值を示したと報告している。北島 ${ }^{37)}$ 多核球が多いは ど collagenase の活性が強く, collagen の減少が強い と述べている.これらの結果当然 collagenase の上昇 は吻合部の脆弱性をもたらす。

著者の実験での病理学的所見の特徵を述べると, 非 治療群では多核白血球浸潤, fibrin 析出が強く認めら れ, 肉芽形成・線維化形成の乏しいことが判明した。 これは资症が強く残存していることを示し, 炎症の存 在は創治悘の遅延・縫合部の脆弱性へと導くことを物 語っている。これに対し，抗生剤群では多核球漫潤は 5 日目で control と同じ程度となり, 肉芽形成・線維化 形成も良好で，炎症がなくなるにつれ創治案の順調な 回復が只られている.その他の特徵としては, heparin 群では多核球浸潤は日ましに減少し炎症所見は軽減す るが縫合部の出血が著明で, 線維化形成がそしいため 縫合部の脆弱性は 7 日目でも認められた.

$$
\text { V.まとめ }
$$

1）細菌性腹膜炎下での結腸縫合は, 腹腔内の非治 療下では適切でない。

2）腹腔内洗浄後の heparin 撒布は腹膜炎治療とし ては有効であるが，縫合部の耐圧力の低下をきたすた め, 結腸吻合を行ら場合の腹腔内治療としては適当で はない.

3）腹腔内洗浄後の PVP-I 撒布は結腸縫合部の 耐圧力を增加させるが, 縫合部虑着が強く, 同様に適 当ではない。

4）腹腔内洗浄後の抗生剂撤布は腹腔内治療とし最 も適当で, 非腹膜炎下の結腸縫合とほぼ差のない良好 な創治痛がえられる。

稿を終るに臨み，終始ご指導ご校閲を賜った恩師勝見正 治教授に深謝の意を捧げるとともに, 絶えず叱正, ご指導を 頂いた浦伸三元講師, 殷田重彦博士ならびに共同研究班の 諸兄，教室の諸兄に深く感謝する.

また，組織病理の面でご指導を賜った中検病理久保邦臣 講師に厚く郝礼申し上げる。

（な拈本論文の要旨は，第34回日本大腸肛門病学会総会， 第16回日本消化器外科学会総会において発表した。）

\section{文献}

1) Hovananian, A.P., et al: An experimental study of the conseqences of intraperitoneal irrigation. Surg. Gynecol. Obstet., 134 : 575-578, 1972.

2) King, D.W., et al : A rabbit model of perforated appendicitis with peritonitis. Br. J. Surg., 62 : 642-644, 1975.

3) Rosato, E.F., et al : Peritoneal lavage treatment in experimental peritonitis. Ann. Surg., 175 : 384-387, 1972.

3）勝部有二：結腸縫合創治瘾に及注す抗癌剂の影響 に関する実験的研究. 日消外会誌, $11: 721-733$, 1978.

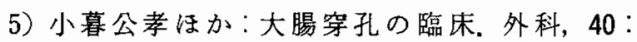
731-740, 1978.

6）森谷宣皓浔か：各種消化管吻合法の比較、最新医 学, 33：1929-1931，1978.

7）鈴木康紀名か：特発性 $\mathrm{S}$ 状結腸穿孔の 1 治験例. 外科, $39: 314-317,1977$.

8）加藤祐之助住か：大腸穿孔。 大腸肛門誌，29： $4-14,1976$.

9) Whelam, C.S., et al. : Surgical management of perforated lesion of the colon with diffusing peritonitis. Am. J. Surg., $121: 374-378,1971$.

10) Kenneth, E. : Resection of the perforated segment. Am. J. Surg., 133:67-72, 1977.

11）牧野永城注か：大腸想室の特質とその治療方針。 手術, 10 : 1045-1052，1976.

12) Stewart D.J. and Motheson, N.A.: Peritoneal lavage in faecal peritonitis in the rat. Br. J. Surg., $65: 57-59,1978$.

13) Sharbaugh, R.J.: A new model for producing experimental fecal peritonitis. Surg. Gynec. Obstet., 133: 843-845, 1971.

14) Nichols, R.L., et al : Peritonitis and intraabdominal abscess; An experimental model for the evaluation of human disease. J. Surg. Res., 25 : 129-134, 1978.

15) Filles, R.M. and Sleeman, H.K. : Pathogenesis of peritonitis. Surg., 61:385-392, 1967.

16) Toni Hau, et al. : Mechanisms of the adjuvant effect of hemoglobin in experimental peritonitis. Surg., $83: 223-229,1978$.

17) Schneierson, S.S., et al : Enhancement of intraperitoneal staphylococcal virulence for mice with different bile salts. Nature., 190 : 829-835, 1965.

18）葛西森夫ほか：急性汎発性腹膜炎の臨床と実験。 外科, $31: 270-276,1968$.

19) Burnett, W.E. et al : The treatment of peritonitis using peritoneal lavage. Ann. Surg., 145 : 675-632, 1957.

20) Stephen, $M$. et al : Continuing peritoneal lavage in high risk peritonitis. Surg., $85: 603-606$, 
1979.

21）大島恥彦注か：穿孔性腹膜炎の化学療法の研究。 日大医誌, $28 ： 1065-1094 ， 1969$.

22）渡辺 晃注か：腹膜炎の新しい治療法。臨外, 26： $37-54,1971$.

23) Sleeman, H.K. et al: Value of antibiotics corticosteroids and peritoneal lavage in the treatment of exprimental peritonitis. Surg., $66: 1060-1066,1969$.

24) Lavigne, J.E., et al : The treament of experimental peritonitis with intraperitoneal Betadine solution. J. Surg. Res., 16:307-311, 1974.

25) Gilmore, O.J.A., et al: Intraperitoneal Povidone-Iodine in peritonitis. J. Surg. Res., 25 : 471-476, 1978.

26) Sindelar, W.F., et al : Intraperitoneal irrigation with Povidone-Iodine solution for the prevention of intraabdominal abscesses in the bacterial contaminated. Surg. Gyne. Obst., 148 : 409-411, 1979.

27) Lagarde, M.C., et al : Intraperitoneal PovidoneIodine in experimental peritonitis. Ann. Surg., $187: 613-619,1978$.

28) Zinsser, H.H. : Experimental study of physical factors, including fibrinformation, influencing the spread of fluids and small particles with and from the peritoneal cavity of the dog. Ann.
Surg., $136: 818-827,1952$.

29) Toni Hau, et al: Anticoagulation in the treatment of experimental peritonitis. Surg. Forum., $27: 458-460,1976$.

30) O'Leary, J.P.: Beneficial effect of minimal Heparin in experimental peritonitis. Surg. Forum., 28:55-57, 1977.

31）岡崎武臣：沉発性腹膜资に抢ける腹腔内超音波洗 浄の応用．東女医誌，49：566--584， 1979.

32) McKenna, J.P., et al: The use of continuous postoperative peritoneal lavage the management of diffuse peritonitis. Surg. Gyne. Obst., $2: 254-258,1970$.

33) Letwin, E., et al : Healing of intestinal anastomoses. Can. J. Surg., $10: 109-116,1967$.

34) Kilam, S.K., et al : Bacterial peritonitis and the bursting strength of intestinal anastomoses. Can. J. Surg., $18: 372-378,1975$.

35) Hawley, P.R., et al. : Etiology of colonic anastomotic leaks. Proc. R. Soc. Med. Suppl., 63 : 28-30, 1970.

36）大高裕一ほか：創傷治矮の形態学. 外科, 32 : 1102-1108, 1970.

37）北島政樹：胃腸吻合創の治痖経過に関する実験的 研究。日外会誌, $75: 538-553,1968$.

38）渡辺洋望活か：これからの創傷治篓研究. 臨外, $30: 991-1001,1975$. 